\title{
Environmental analysis in construction company economic activity: approaches, methods, indicators
}

\author{
Nina Simionova ${ }^{1, *}$, Irina Krivosheeva ${ }^{1}$, Dmitriy Krivosheev ${ }^{1}$ and Mikhail Lunyakov ${ }^{2}$ \\ ${ }^{1}$ Don State Technical University, pl. Gagarina, 1, 344010, Rostov-on-Don, Russia \\ ${ }^{2}$ Moscow State University of Civil Engineering, Yaroslavskoe shosse, 26, Moscow, 129337, Russia
}

\begin{abstract}
Taking into account that construction is one of the resourceintensive economic sectors, which is reflected in natural capital consumption and taking out the land resources from the turnover, it significantly affects the environmental situation. The conducted review of the previous research in the environmental analysis confirms the importance of the aforementioned problem and the urgency of research continuation to develop a tool for the environmental subsystem management in terms of companies' sustainable development management. As a uniting tool for quantitative and qualitative analytical methods providing the basis for the choice and implementation of the strategy taking into account environmental requirements, we proposed a method for building of a construction company environmental profile, a scorecard with specific indicators underlying such profile as well as approaches for their reference level formation. To ensure the growth of the companies' environmental responsibility, it was proposed to increase the range of the estimated figures used for the formation of the construction companies' rankings including the environmental indicators into the system alongside with the economic and social figures with the account of the achieved outcomes both on the basis of the instantaneous and rate indicators.
\end{abstract}

\section{Introduction}

The modern approach to the comprehensive analysis system of the economic entities' activity is based on the concept of the sustainable development management, which was recorded in the papers of many scientists [1-5]. The overview of the previously conducted research outcomes makes us draw a conclusion that the environmental subsystem analysis is understudied, which makes it rather questionable that there is any comprehensive and systematic approach to the sustainable development management. We need to control the negative impact the economic activity has on the environment. The key competitive and investment attractiveness factors shall depend on the availability of the certified environmental management systems complying with the international standards ISO 14001

\footnotetext{
* Corresponding author: simionova@rambler.ru
} 
and EMAS in construction companies. It is important of assess the efficiency of the environmental management systems operating in the companies. Continuously toughened requirements to the environmental responsibility of a company shall be reflected in the company management system. To improve the company's goodwill, enhance investors' confidence and increase public loyalty, the company's environmental indicators shall be controlled and thus included in the system of the company's economic activity comprehensive analysis. Considering the development stages of the company's economic activity comprehensive analysis, A.D. Sheremet points out that a contemporary development stage shall be characterized as an economic, social, and environmental analysis of the company's sustainable development. "The time when companies were concerned with their financial issues only has gone, or, to be more accurate, shall be gone" [1, p.4]. It is necessary to continue the research and to form the system in the following directions [1]:

- offering the system of environmental indicators alongside with the basis for comparative measurements complying with the economic reality and global social trends.

- developing the method for the analysis of the environmental indicators influence on the financial and economic ones as well as the assessment of the reverse influence.

One can notice the environmental subsystems are underestimated within the comprehensive analysis of the company's economic activity while analyzing the approaches to the consideration of such essential categories as competitiveness of both the construction industry and construction companies. Studying the competitiveness of the companies including construction ones, the researchers offer such criteria as the price, quality, terms; however, they do not take into account the economic entity social and environmental responsibility. This can relate to the innovative business strategies chosen only for financial sustainability enhancement [6-8]. The system will not change until there are organizations capable of environmental issues solution in place when it is necessary to become environmentally efficient to increase competitiveness and to take part in tenders and to be included in the rankings.

The research demonstrate that the analysis of the factors influencing the process of decision taking relating to investment and innovative project funding does not include the environmental factors in any way: neither as promoting positive decision taking nor preventing ones [9]. Besides, the environmental factors are not considered while the substantiation of technical re-equipment options at manufacturing facilities and while choosing the technology for future facility at the design stage. Very few research take into account this aspect. In particular, they search for the maximum utility function in the range of indicators including pollutant emissions into the environment [10].

The balanced scorecard proposed by Norton and Kaplan [11] became widespread in the national research although neither the authors nor their followers completed the system with the environmental component. In general, contemporary approaches and methods of the economic activity comprehensive analysis reflect financial issues ignoring the environmental ones. To the same extent it can be referred to the development of a scorecard to evaluate the efficiency of investment and innovative projects, which needs to be revised $[2,6,9,12]$. One of the rules the organization must stick to when making its strategy is the one defining the interrelations between such company and the environment in a broad sense [13]. Thus, the environmental factors shall not be considered the last of all. Everything points to the necessity of a broader and fuller reflection of environmental indicators in the organization analytical scorecard.

\section{Compilation of indicators proposed in the research to analyze the environmental component within the comprehensive management analysis of the economic entity activities}


Environmental requirements' tightening is irreversible and the environmental management subsystem shall be developed; it is necessary to introduce environmental forecasting, longterm environmental planning and environmental control system building. It is necessary to develop the environmental unit system within the broader comprehensive analysis system of the organization economic activity. One of the possible approaches to the solution of a multicriteria problem of the economic entity activities optimization by environmental parameters is the operation environment analysis. In particular, the authors consider the opportunity of accounting for the following parameters to calculate the organization eco-efficiency [14]: atmospheric emissions, thousand tons; solid wastes, thousand tons; water abstraction, million $\mathrm{m}^{3}$; excessive negative impact (expenses growth); insufficient positive impact (production drop). Providing a certain specialization, these indicators can be included in the analysis (in particular, the latter two).

The environmental requirements' tightening is irreversible and the environmental management subsystem shall be developed; it is necessary to introduce environmental forecasting, long-term environmental planning and environmental control system building which will allow for expenses cut. It is necessary to develop the environmental unit system within the broader comprehensive analysis system of the organization economic activity.

Eco-building is a prospective activity pursued by construction companies targeted at the maximum account of the environmental factors with the minimum environmental impact and natural resources consumption including the process of the facility operation $[15,16]$. At the same time, one needs specific indicators calculated per 1 square meter of a total area and corresponding regulations.

At the present time there is no a comprehensive method for the natural capital comprehensive analysis while the approaches and analytical tools evaluating the natural capital use efficiency as well as the efficiency of the organization environment protection are ambiguous. A certain basis for analysis is provided by the international standard intended for macro ecologo-economic accounting [20]. This standard may also underlie the development of the analytical method for natural capital use at the organization level as this document contains the definitions of environmental assets, natural resources flows, the principles of their accounting and resource rent calculation. The Sustainability Reporting Guidelines [17] provides the structure of the environmental assets information and their influence on the environment represented by the following indicators:

- consumption of non-renewable and renewable materials for manufacturing;

- energy sources and consumption from renewable and non-renewable sources;

- types and volume of emissions, effluents, waste;

- general expenses and investments into environmental protection, etc.

The concept of technogenic economic development is based upon a wider use of artificial manufacturing facilities; it is implemented within the specific companies without the account of environmental consequences. The key factors recognized as providing for economic growth are labour and capital while the global economic integration processes require to take into account environmental limitations [18]. Total expenses the organization incur due to environmental reasons $\mathrm{R}(\Delta \mathrm{T})$ are summed up as follows:

$$
\mathrm{R}(\Delta \mathrm{T})=\mathrm{S}(\Delta \mathrm{T})+\mathrm{W}(\Delta \mathrm{T})+\mathrm{V}(\Delta \mathrm{T})
$$

where $\mathrm{S}(\Delta \mathrm{T})$ is the total of environmental payment for emissions in the atmosphere, effluents and waste disposal for the period; $\mathrm{W}(\Delta \mathrm{T})$ - accidental value equal to the environmental fee payment for the period; $\mathrm{V}(\Delta \mathrm{T})$ - expenses for funds depreciation of the environmental subsystem, its functioning and development.

This method can be applied for construction organizations and provide the basis for specific indicators by means of comparison with the revenues and profit. 
As the natural capital evaluation lies at the intersection of economic an environmental management subsystems, it is necessary to consider both economic an environmental assets as a whole [19]. Despite the fact the conceptual approaches to the natural capital analysis, its use and the consequences thereof are generally determined, to include the environmental analysis unit into the comprehensive analysis of the economic activity, it is necessary to develop a deeper approach to the problem and identify its specific features. The features imply that such analysis shall cover interdependence of the environmental assets value, use of natural resources, production output, natural protection expenses and the volume of emissions, effluents, waste. The interdependence of these indicators characterizes not only the efficiency of environmental assets use but also the manufacturing facility environmental impact [20].

To evaluate the natural capital use, one needs to obtain the information on the changes both in physical and value forms and the factors that influenced these changes. The following indicators similar to the indicators applied for the fixed assets analysis [21] can be partially used for this purpose as well, in particular:

1. Resource productivity(PONC):

$$
\mathrm{PONC}=\frac{\mathrm{TR}}{\mathrm{NC}_{\mathrm{i}}},
$$

where $\mathrm{TR}$ - revenue; $\mathrm{NCi}$ - used natural capital volume or cost.

2. Material intensity of use (MC):

$$
\mathrm{MC}=\frac{\mathrm{ME}}{\mathrm{TR}},
$$

where $\mathrm{ME}$ - consumption of non-renewable and renewable materials.

3. Energy intensity (PC):

$$
\mathrm{PC}=\frac{\mathrm{P}}{\mathrm{TR}}
$$

where $\mathrm{P}$ - energy consumption.

4. Specific water consumption (WC):

$$
\mathrm{WC}=\frac{\mathrm{W}}{\mathrm{TR}}
$$

where $\mathrm{W}$ - water consumption.

It is proposed to find out the natural protection activity efficiency with the help of the following scorecard [20]:

5. Value of negative externalities $\left(\mathrm{k}_{\mathrm{E}}\right)$ :

$$
\mathrm{k}_{\mathrm{E}}=\frac{\mathrm{E}}{\mathrm{TR}},
$$

where $\mathrm{E}$ - emissions, effluents, discharge

6. Products tax to revenue ratio $\left(\mathrm{NC}_{\mathrm{E}}\right)$ :

$$
N C_{E}=\frac{T E}{T R},
$$

where TE - environmental taxes and other environmental payments.

7. Resource rent (RR):

$$
\mathrm{RR}=\mathrm{NP}+\mathrm{T}_{\mathrm{p}}-\mathrm{S}_{\mathrm{p}}-\mathrm{r}_{\mathrm{E}} \cdot \mathrm{E}-\mathrm{ED},
$$

where NP - net profit; Tp - targeted taxes imposed on resource development; $\mathrm{r}_{\mathrm{E}}$-targeted subsidies; E - equity; ED - environmental damage. 
We face a problem of comparative measurements. To manage sustainable management processes, one needs not only static but also dynamic assessment of the achieved results based upon the arrangement of indicator change rates which will provide for the best system functioning mode [3]. Comparison of the reference and actual dynamics allows for determining of the balance level of the company's social, economic and environmental activities. In particular, a dynamic normal for environmental management can be expressed by the following inequality:

$$
\begin{gathered}
\mathrm{TP}_{\mathrm{MT}}>1>\mathrm{TP}_{\mathrm{N}} \text { and } \mathrm{TP}_{\mathrm{G}}>1>\mathrm{TP}_{\mathrm{N}} \\
\mathrm{TP}_{\mathrm{MT}}>1>\mathrm{TP}_{\mathrm{N}} \\
\mathrm{TP}_{\mathrm{G}}>1>\mathrm{TP}_{\mathrm{N}}
\end{gathered}
$$

where $\mathrm{TP}_{\mathrm{MT}}-$ growth rate of low-waste and sustainable technologies; $\mathrm{TP}_{\mathrm{N}}$-natural resource intensity rate; $\mathrm{TP}_{\mathrm{G}-}$ growth rate of natural protection activities.

The key factor shall become the product natural resource intensity characterizing resource consumption during manufacturing. One shall calculate a specific indicator per production unit [20]. The natural capital is the intersection of environmental and economic subsystems being a part of both and representing natural resources and land. To analyze the natural capital, the literature proposes the following financial and non-financial indicators including environmental ones [20]. From this list we selected the following criteria to apply in the construction industry:

- total weight of waste, effluents, emissions per types;

- materials made from recycled or processed waste;

- energy saved as a result of the measures intended for the reduction of energy consumption and energy efficiency enhancement.

The company accounting and analytical system shall satisfy the information requests of all the involved groups to the fullest possible extent. Considering the composition of the accounting and analytical support of the organization sustainability management, identifies environmental accounting, reporting and analysis as the components of the environmental accounting and analytical system [4]. Therefore, not only the scorecard but also properly organized accounting and reporting as necessary information sources for analysis conduct are important for the environmental subsystem management.

\section{Results}

\subsection{Environmental profile of a construction company as the environmental subsystem management tool}

Even having a scorecard to evaluate the real state of the sustainability management environmental subsystem in the company, the problems of the proper strategy choice still occur. Thus, the problem occurs in terms of complementarity of the environmental innovations and the company financial sustainability preservation.

One of the efficient tools for the development of the sustainability strategy with the account of environmental factors is the company environmental profile building. Such environmental profile building is based upon the reasonable combination of quantitative and qualitative analytical methods allowing for the opportunity to identify strategic reserves. The environmental profile establishes the balance of external requests and real opportunities of a specific company. To do this, one needs:

- to develop a balanced system of the company environmental indicators; 
- to establish reference indicator values ensuring the company's competitiveness and compliance with environmental standards reflecting the contemporary realities of the construction company activities;

- to asses the compliance of the achieved indicator level with their reference values.

To identify deviations from the reference values, one can apply various metrics, in particular, the Manhattan distance. The Manhattan distance standardized in a high quality manner has both the lower limit equal to zero and the upper limit equal to one. As a scale for the facility vicinity determination the following gradation is established:

- $\mathrm{W}(\mathrm{k})=1 \quad$ absolute vicinity;

- $0.91 \leq \mathrm{W}(\mathrm{k})<1 \quad$ excellent vicinity ;

- $0.90 \leq \mathrm{W}(\mathrm{k})<0.81$ good vicinity;

- $0.80 \leq \mathrm{W}(\mathrm{k})<0.71$ satisfactory vicinity;

- $\mathrm{W}(\mathrm{k})<0.70$ unsatisfactory vicinity.

As a balanced scorecard with the indicators that may be taken as the basis for the company's environmental profile building, we suggest the following (Table 1).

Table 1. Indicators necessary to be taken into account for the environmental profile building.

\begin{tabular}{|l|l|l|}
\hline No. & \multicolumn{1}{|c|}{ Indicators } & \multicolumn{1}{|c|}{ Reference value } \\
\hline 1 & $\begin{array}{l}\text { Environmental payments for environmental } \\
\text { pollution, rubles/rubles of revenue }\end{array}$ & $\begin{array}{l}\text { Level of planned changes due to } \\
\text { environmental measures implementation }\end{array}$ \\
\hline 2 & Environmental fines, rubles/rubles of revenue & $\begin{array}{l}\text { Level of planned changes due to } \\
\text { environmental measures implementation }\end{array}$ \\
\hline 3 & Use of natural capital return rate & $\begin{array}{l}\text { Level of planned changes due to } \\
\text { environmental measures implementation }\end{array}$ \\
\hline 4 & $\begin{array}{l}\text { Energy intensity of construction products } \\
\text { manufacture calculated per 1 square meter of } \\
\text { a total area }\end{array}$ & $\begin{array}{l}\text { At the level of the advanced technology } \\
\text { requirements }\end{array}$ \\
\hline 5 & $\begin{array}{l}\text { Material intensity of use of the construction } \\
\text { industry, rubles/rubles of revenue }\end{array}$ & $\begin{array}{l}\text { Level of the best system functioning } \\
\text { mode }\end{array}$ \\
\hline 6 & $\begin{array}{l}\text { Tax to revenue ratio of construction products } \\
\text { on environmental taxes, fines and payments, } \\
\text { rubles|rubles of revenue }\end{array}$ & $\begin{array}{l}\text { Level of planned changes due to } \\
\text { environmental measures implementation }\end{array}$ \\
\hline 7 & $\begin{array}{l}\text { Energy intensity of construction products at } \\
\text { the operation stage calculated per 1 square } \\
\text { meter of a total area }\end{array}$ & $\begin{array}{l}\text { Level of the best system functioning } \\
\text { mode }\end{array}$ \\
\hline
\end{tabular}

Developed environmental profile of a standard company based upon the scorecard within the research (Table 2). 
Table 2. Company environmental profile.

\begin{tabular}{|c|c|c|c|c|}
\hline \multirow[t]{2}{*}{ Indicators } & \multicolumn{4}{|c|}{$\begin{array}{l}\text { Level of compliance with the required level of } \\
\text { indicators }\end{array}$} \\
\hline & Up to 0.7 & $0.71-0.80$ & $0.81-0.90$ & $0.91-1.0$ \\
\hline $\begin{array}{c}\text { Environmental payments for } \\
\text { environmental pollution, rubles/rubles } \\
\text { of revenue }\end{array}$ & & & & \\
\hline $\begin{array}{c}\text { Environmental fines, rubles/rubles of } \\
\text { revenue }\end{array}$ & & & & \\
\hline Use of natural capital return rate & & & & \\
\hline $\begin{array}{c}\text { Energy intensity of construction } \\
\text { products manufacture calculated per } 1 \\
\text { square meter of a total area }\end{array}$ & & & & \\
\hline $\begin{array}{l}\text { Material intensity of use of the } \\
\text { construction industry, rubles/rubles of } \\
\text { revenue }\end{array}$ & & & & \\
\hline $\begin{array}{c}\text { Tax to revenue ratio of construction } \\
\text { products on environmental taxes, fines } \\
\text { and payments, rubles/rubles of } \\
\text { revenue }\end{array}$ & & & & \\
\hline $\begin{array}{l}\text { Energy intensity of construction } \\
\text { products at the operation stage } \\
\text { calculated per } 1 \text { square meter of a } \\
\text { total area }\end{array}$ & & & & \\
\hline
\end{tabular}

The developed environmental profile will allow for the consideration of product strategy options and choose the option providing for environmental progress without economic sustainability loss.

\subsection{Environmental indicators within the ranking score of construction companies}

The environmental management system functioning within construction companies will operate in a more efficient way providing toughening of the conditions for contractors' selection to implement large investment projects. To do this, the company can apply the tool of comparative ranking score. The algorithm for the comparative ranking score implies identification of a reference company in the list of companies with the maximum indicator value (it can be the minimum value for several indicators).

Matrix initial indicators $a_{i j}(i=1,2,3 \ldots n$ - numbers of indicators; $j=1,2,3 \ldots \mathrm{m}$ - numbers of companies) are standardized in relation to the corresponding value of the chosen reference company opt $_{j} a_{i}$ according to the formula:

$$
x_{i j}=\frac{a_{i}}{\operatorname{opt}_{j} a_{i}},
$$

where $x_{i j}$ - standardized values of the $\mathrm{j}$ company.

The ranking score for each company is calculated as follows:

$$
P_{j}=\sum \sqrt{k_{j}^{*}\left(1 \pm x_{i j}\right)^{2}}
$$

where $k_{j}$ - weight coefficient 
The companies are ranked in the descending order of the ranking score. The list of ranking score indicators can be very broad and cover all the activity aspects but it is recommended to systematize them in the following categories [1]:

- economic sustainability indicators;

- social sustainability indicators;

- environmental sustainability indicators.

Ranking score shall become one of the criterion for the construction company competitiveness measurement including not only instantaneous but also rate indicators. We suggest taking the following ranking score indicators of the construction companies' environmental sustainability (without involving economic and social indicators):

- extent of environmental focus of all the economic activities;

- used land resources calculated per 1 square meter of the facilities' total area;

- energy intensity of the operation of ready construction products;

- negative externalities (total weight of waste, effluents, emissions according to various types);

- availability of the certified environmental management systems;

- current expenses for natural protection measures;

- investments in the natural protection projects;

- expenses for the environmental subsystem fund depreciation, the system functioning and development;

- share of revenues for the eco-construction facilities of the total sales revenue;

- total of environmental fines for the period;

- growth rate of the expenses for natural protection measures;

- availability of environmental indicators in the quality management system.

\section{Issues for discussion}

Issues for discussion:

1. Proper positioning of the environmental management system within the integrated management system.

2. The system of the environmental accounting and reporting organization in the company including within business processes.

3. Search for the methods to boost the environmental activities of the companies.

\section{Conclusion}

The research demonstrated the existence of certain problems in the comprehensive analysis of the companies' economic activity with the account of the environmental management subsystem but there are other ways to resolve the problem. The authors believe the further search for the analytical system development areas shall focus on:

- necessity to find the way the reflect of the system for the environmental analysis of regional peculiarities of the construction companies' activity to influence the product sales and expenses;

- necessity to propose the method for identification of the influence of the company's environmental activity on market capitalization.

\section{References}

1. A.D. Sheremet, Economic analysis: Theory and Practice 45(396), 106-118 (2014) 
2. S.I. Krylov, Economic Analysis: Theory and Practice 18(417), 2-14 (2015)

3. E.A. Tretyakova, T.V. Alferova, Economic analysis: Theory and Practice 9(456), 86-99 (2016)

4. I.V. Kalnitskaya, Economic Analysis: Theory and Practice 17(416), 21-32 (2015)

5. M.R. Tsibulnikova, Bulletin of Tomsk State University 366, 168-171 (2013)

6. V.M. Serov, Construction Economics 4(46), 54-65 (2017)

7. V.M. Serov, Construction Economics 5(41), 32-38 (2016)

8. D.N. Roman, Construction Economics 5(41), 62-68 (2016)

9. V.N. Belenov, V.V. Trofimov, V.N. Khaver, Economic Analysis: Theory and Practice 16(1), 59-65 (2017)

10. D.V. Troshin, Economic Analysis: Theory and Practice 13(364), 12-22 (2014)

11. R. Kaplan, D. Norton, Balanced Scorecard (Olymp Business, CJSC, Moscow, 2003)

12. A.G. Plekhanov, T.V. Ushakova, M.V. Pavlova, Construction Economics 4(46), 65-70 (2017)

13. I. Ansoff, New Corporate Strategic Programme (Piter, Saint-Petersburg, 2009)

14. Ye.Yu. Khrustalev, P.D. Ratner, Economic Analysis: Theory and Practice 35(434), 33$42(2015)$

15. Ye.A. Prokhin, Construction Economics 5(41), 11-15 (2016)

16. Ye.A. Yevdokimov, Ye.S. Ozyerov, Construction Economics 4(46), 71-76 (2017)

17. Sustainability Reporting Guidelines, http://рспп.pф/12/11958.pdf

18. V.N. Yegorov, M.V. Chernova, Economic Analysis: Theory and Practice 8(407), 38-46 (2015)

19. Central Basis. System for Environmental and Economic Accounting, URL:http://unstats/org/unsd/env accaunting/seearev/CE_trans/R_march 2014. pdf

20. M.V. Myelnik, V.G. Kogdenko, Economic Analysis: Theory and Practice 4(451), 72-84 (2016)

21. V.G. Kordenko, Corporate Financial Policy (UNITY - DANA, Moscow, 2014) 